\title{
The Legal Protection on Lands of Former Mines Which has Implications to the Environment
}

\author{
Zulfikar \\ Students of Doctoral Program of Law \\ Universitas Borobudur \\ Jakarta, Indonesia \\ zulfikar10710@yahoo.com
}

\author{
Ilham Djaya \\ Students of Doctoral Program of Law \\ Universitas Borobudur \\ Jakarta, Indonesia \\ ilhamdjaya02@gmail.com \\ Faisal Santiago \\ Faculty of Law \\ Universitas Borobudur \\ Jakarta, Indonesia \\ faisalsantiago@borobudur.ac.id
}

\author{
Heri Sujoko \\ Students of Doctoral Program of Law \\ Universitas Borobudur \\ Jakarta, Indonesia \\ herysujoko70@gmail.com
}

\begin{abstract}
Mining activities are activities that have high potential to damage the environment and cause the balance of ecosystems to be disturbed, then the reclamation and postmining activities have its own problems to be tested further. Forms of legal protection on mined land under the Minerals and Coal Act only impose administrative sanctions in the form of reprimands, suspension of activities and revocation of business licenses to holders of business licenses. While reclamation and post-mining are commonly done when mining activities are over, this makes legal protection for mining areas need to be found for legal certainty. Meanwhile, the Environmental Protection and Management Act as a legal umbrella on all environmental issues implicitly also regulates the same object as the Mineral and Coal Act, but gives different sanctions to the same deeds. Therefore it is a matter that needs to be found how the legal certainty of sanctions given in two different legislation but its hierarchical position parallel, and which agency who is in charge and responsible for the imposition of sanctions. The research method used in this research is Normative Law Research Approach with Statutory Approach (Statute Approach). This approach reviews laws and regulations as the main point of analysis in reviewing and discussing legal issues. Through this Legislation Approach, the Author examines this research by looking at legal uncertainty and legal intersections in a legal event. Comparisons of sanctions in the Minerals and Coal Act with the Environmental Protection and Management Act on the same object shall be conducted in accordance with the prevailing laws and regulations prevailing in Indonesia.
\end{abstract}

Keywords- legal protection, land of former mine, environment

\section{INTRODUCTION}

Indonesia is a country which is rich in minerals (mining).The excavated material including gold, silver, copper, oil and gas, coal and others. The excavation material is controlled by the state.The right of state ownership shall have the authority to regulate, manage and supervise the management or exploitation of minerals, and shall bear the obligation to utilize them as much as possible for the welfare of the people. State control is administered by the government. With the aim of the creation of mining areas that integrally take into account the ecological, economic and socio-cultural aspects as well as environmental insightful, the Law No. 4 of 2009 on minerals and coal in Article 39 paragraph (2) letter $\mathrm{j}$ explains that to every holder of mining business license (hereinafter referred to as IUP) the production operation shall contain at least the obligation to safeguard the environment one of them by implementing reclamation and post-mining obligations. It is also reemphasized in article 96 letter c which requires that in the application of good mining technique rules, IUP holders and special mining business permits (hereinafter referred to as IUPK) shall perform the management and monitoring of the mining environment, including reclamation and post-mining activities.

Until now, Indonesia as one of the countries with abundant mining products has not been able to provide concrete and firm sanctions to business owners in the mining sector who have not run the mining rules perfectly, in this case the obligation to carry out reclamation and post of mining. Strict and concrete sanctions are expected to make every business owner in the mining sector care about environmental sustainability after for some time the land is exploited for economic purposes. Reclamation under the provisions of Law No. 4 of 2009 on minerals and coal shall be activities carried out throughout the mining business to organize, restore and improve the quality of the environment and ecosystem in order to function again.

Humans as one of the living things that have many activities in the environment, play a very important role in maintaining the stability of ecosystems. Law as a rule or norm governing the behavior of human life one of them also aims to prevent damage to the ecosystem that affects the sustainability of the lives of all living things. The magnitude of the potential of Indonesia's natural products, especially in mining activities should not focus only on the maximum economic benefits, but also must pay attention to environmental sustainability for the foreseeable future.

The nature of the mining business, especially open pit mining (5), always changing the landscape so as to affect the ecosystem, which in large scale will disrupt the balance of environmental functions and adversely affect human life. with this image, mining efforts tend to be rejected by local communities. This image is exacerbated by the number of 
illegal mining (PETI) that is very damaging to the environment. [1].

Based on the Living environment facility (WALHI) report, one of the cases was found in Bangka Belitung province that the implementation of reclamation by one mining company, PT Timah in 2010, did not reach the target. Only about $12.58 \%$ tree planting on mining land. WALHI said that mining companies, especially PT Timah, failed to reclaim the ex-mining lands, causing various environmental problems and causing various diseases to communities around the former mining area. As a result of no structuring, the land is eroded by water and erosion occurs in most community land because of the absence of erosion control channels and water control channels.

In ex-mining land, mound of unfinished excavated mound is found, making it more difficult for maintenance accessibility, monitoring and quality of plant health. According to one of the organizations focusing on environmental issues, the Forum for the Environment (WALHI), the failure of reclamation is not only due to the presence of unconventional tin miners, but this failure has been a classic problem due to the lack of supervision and action from local governments to companies that do not perform their obligations to the environment and society.

In 2007 recorded a reclamation that should have been $19,207.15$ hectares, but only realized $8,662.20$ hectares or 45.10 percent, so that land that has not been reclaimed reached 10,544.95 hectares. The issue of mine reclamation is still ongoing today, due to the lack of awareness of the entrepreneurs to plant in the former mine and the government's negligence in overseeing the policy on reclamation.

The problem of reclamation and post-mining on the former mining land must be seriously resolved by all parties involved, especially the Government. Because the losses of the State that have or potentially experienced can not be continuously allowed. Not only economic losses that have been suffered but ecological losses must also be resolved immediately and improved because the environment is an important aspect in life that directly intercrops with humans and other living things.

Indonesia is abundant with its natural wealth in the field of mining which still has not been able to provide prosperity for the people, especially those who are in the area around the mining area.The surrounding communities whose territories have been taken over to be managed by the private sector through mining permits are no longer able to conduct conventional mining, thus making the livelihoods of the people disturbed. Now people also have to accept the environmental and sociological impacts with no reclamation and post-mining activities done by business actors who have completed mining activities.

Based on the background of the problems that have been mentioned above, then the formulation of the problem in this study are: How Legal Certainty Legal Sanctions on mining land due to non-implementation of reclamation and postmining obligations?

\section{DISCUSSION}

\section{A. Mine Former Land as the Object of Environmental Protection}

Everything in this world is closely related to each other. Between man and man, between man and beast, between man and plants and even between humans and even inanimate objects. Similarly, between animals and animals, between animals and plants, between animals with humans and between animals and objects of dead objects around it. The influence of one component with other components is various shapes and their properties [2].

An event that befalls a person, can be summed up as a resultant result of various influences around him. So much influence pushes humanity into a certain condition, so that man then tries to understand what really affects him, and to what extent these influences are. Thus, it develops what is called Ecology, a science that studies the relationship between one organism with another, and between the organism and its environment [3].

The ecosystem as a system consists of various sub systems, or sub-ecosystems, such as marine sub-ecosystems, terrestrial sub-ecosystems, lake sub-systems, forest subecosystems and desert sub-ecosystems. Between various subsystems or sub-ecosystems interact, mutual influence and mutual support so that there is also the flow of matter, energy and information[4]. The environment is a complex system that lies outside the individual that affects the growth and development of the organism [5]. Environmental issues cover a very wide range of spaces, mountain tops, down to the bowels of the earth and the seabed and include human resources, biological resources, non-biological resources and artificial resources. Such material may not be fully regulated in a single law, but requires a set of legislation in a similar direction.

Therefore, the nature of UU PPLH regulates the basic stipulations of environmental management containing the basic principles, thus functioning as a "social" (umbrella act) for the compilers of other legislation related to the environment and for the adjustment of legislation which already exists [2]. The living environment consisting of two elements or components, namely elements or components of living things (biotic) and elements or components of the creature does not live (abiotic) resulting in a reciprocal relationship,

Science that studies the mutual relationship and unity between individuals (living things) with things that are outside is called Ecology. Ecology is one of the disciplines studied from the branch of Environmental Biology, the term Ecology was used in 1869 by Ernst Haeckel, a German Biologist. [6]. In addition there are also said that ecology is a science that tries to study the relationship between plants, animals, and humans with the environment in which they live, how life and why they are there. Ecology only learns what is and what is going on in nature by not doing experiments [7]. Human life and the environment are two things that are mutually sustainable. Human attitudes and behavior determine how environmental quality will take place, and the environment will determine how it functions against humans and other living things.

Nature that can physically be exploited for the benefit of human in strive for a better life and healthy become not good 
and not healthy and can also vice versa. The reciprocal relationship is called the Ecosystem. In the ecosystem concept the various elements in the environment are not seen separately, but rather thoroughly, integrated in the interrelated components in a system [8]. Mining activities that have a very significant impact on the environment make mining in the concept of ecosystems can not be released with the environment, so that the wider environment is not only the physical and biological environment by nature, but also includes the efforts made by humans to meet the various aspect of need in his life economically, socially and culturally. Based on the above description, it can be concluded that the former mining area is also part of environmental objects that are not supervised by the management process, also protected the sustainability of land after mining activities carried out. Although not explicitly explained, it can be concluded that the former mining area is also included in the object protected by Law No. 32 of 2009 on Environmental Protection and Management.

\section{B. Environmental Damage Due to the Reclamation of post mining is not Implemented}

Mining is an activity of earth exploitation that can lead to landscape changes. Changes include the changes of:

\section{Topography.}

2. Vegetation Cover.

3. Hydrological Patterns.

4. Damage to the body of the soil

Changes in the landscape result in the destruction of the ecosystem because the mining industry is one of the most potential destroyers for the environment. Damage to mining land is generally determined by two parameters:

\section{Type of minerals}

In the context of minerals and coal, mineral excavation materials are commonly mixed in the mother rock, requiring crushing and purification with certain chemicals. Minerals requiring such purification will produce tailings containing hazardous chemicals or high concentrations of metals typically in the form of mud or sand.

\section{Mining techniques to obtain minerals}

Mining of minerals and coal which generally use open pit mining causes soil damage, such as:

a. Physical damage, because open mining makes land on ex-mining land has a very high bulk destiny, it will make it difficult for the soil to pass water to be penetrated into the roots of the plant.

b. Chemical damage, due to land clearing in the soil, this makes in the former land mines of plant vegetation problematic.

c. Biological damage, due to the removal of soil above the deposit of minerals, causes the organic matter content in the soil to decrease and otherwise increase the soil acid level.

In addition to the impacts described above, the biogeophysical aspects of environmental impacts due to mining land also have an important impact on water bodies. Particularly to the aspect of water quality. This water quality decrease can be measured quantitatively and qualitatively.
Quantitatively can be characterized by the decrease of groundwater or river flow, and qualitatively can be seen visually on the physical condition of turbid water and chemically lead to increased concentration of elements or harmful compounds for biota or humans.

Based on the above explanation, in general what must be done to overcome the impact of environmental damage is to reclaim the former mining area. To rehabilitate or reclaim former mining land is to improve soil reconstruction so that the process of revegetation with crops on post-mining land is still running and does not damage the ecosystem because the damage to the soil, especially humus soil can affect crops resulting in loss of vegetation in the ecosystem. These efforts also indirectly prevent the formation of AAT. Ex-mining land is not always returned to the original designation. This depends on determining the land use of the area. But whatever is planned in the process of land-use determination, essentially still have to restore land allotment as one important element in maintaining the ecosystem.

There are two events that are considered to disturb the environmental stability of destruction and pollution. [9]. Environmental destruction is the act of a conscious or unconscious human being, directly or indirectly resulting in the destruction of an environment. Another type of environmental damage is contamination. Environmental Pollution is the entry or inclusion of living things, substances, energy or other components into an environment and or the change of environmental order by human activities or by natural processes resulting in degradation of environmental quality, so that it can not function properly. [9]. Forms of Pollution can be categorized into 3 types, among others:

1. Air pollution, air is an important factor in life, but with the increasing physical development of cities and industrial centers, air quality has changed. [10]. Air pollution is generally caused by the entry of gas contaminants or small particles into the air resulting in changes in environmental balance.

2. Water pollution, water is a natural resource to meet the life of the people, so it needs to be maintained in order to maintain the quality of life and life of humans and other living creatures with the control of water pollution. [11].

3. Pollution of soil, Soil as Open Pedosystem has a real influence, not only on crop ecosystem but also on animal ecosystem and to wider system, including human [12]. (The soil contaminants can be divided into two, ie inorganic materials and organic materials, such as heavy metals such as Zinc and Lead $(\mathrm{Pb})$, whereas organic materials are usually chemical compounds made by man for example pesticides.

\section{Environmental Laws of Criminal Justice as One of the Legal Protection Instruments on land of former mine}

Among legal experts there are still frequent disagreements over the use of the term "environmental criminal law" and "environmental law of crime". For Andi Hamzah, this is not really a mistake. According to him, if we write "environmental law" then there are aspects of criminal, administrative, and civil law, but when we write the crime only, it is not wrong if we use the term "environmental criminal law". So it depends on which perspective the term is used [13]. 
In this case the term "criminal law" will be used because it is nothing but an environmental law containing criminal aspects (strafrechtelijk milieurecht), rather than speaking in the context of criminal law in general. This is because since environmental law is a new branch of legal science that is self-contained and has many aspects, one of which is criminal. The enforcement of environmental laws can be done in a preventive and repressive manner according to their nature and effectiveness. Instruments for preventive law enforcement include counseling, monitoring and use of supervisory authority such as sampling, cessation of machinery and so on. The enforcement of repressive law is done in the case of acts that violate the rules and usually can not negate the consequences of the violation [4]. This underlies the basis of crime that should be done in an effort to reduce and / or stop environmental damage due to nonreclamation and post-mining activities.

In the punishment to be carried out, environmental law has principles that can support the punishment process, among others [14]:

\section{Subsidiarity Principle}

The word subsidiarity in the English dictionary of Indonesia Jhohn Echols and Hassan Shadily found the word "subsidiary" which implies an additional branch. Likewise, in the legal dictionary you can get the word subsidair meaningful substitute, additional, if the principal does not happen or can be done, then as a replacement. In the Dutch Indonesian general dictionary found the word subsidiair meaning as a substitute, or. Whereas in Black's Law Dictionary subsidiary means subordínate, under another's control. The principle of subsidiarity is contained in the general explanation in point 7 of Law No. 23 of 1997 on Environmental Management:

"That as a matter of administrative law, the enactment of criminal law stipulates the principle of subsidiarity, namely that criminal law should be utilized if other legal sanctions, such as administrative sanctions and civil sanctions, and alternatives to environmental dispute resolution have been declared ineffective, the perpetrator's errors are relatively heavy, and / or his actions are relatively large and / or his actions cause public unrest ".

Criminal law enforcement is subsidiarity means the enforcement of criminal law solely to support the enforcement of administrative law and / or civil law enforcement whether completed in Court or through mediation or conciliation. When the enforcement of administrative law and civil law had been not effective implementation then operationalized criminal law enforcement. This is what is meant by the application of criminal law while considering the principle of subsidiarity because in the things mentioned above, the function of criminal law is only as a supporter of administrative law, civil law in the Court and outside the Court through Alternative of Dispute Mechanism (MAPS). The principle of subsidiarity for the utilization of criminal instruments is as a branch (non-principal) or in the form of an addition or substitute if the utilization of administrative law instruments and civil law and dispute settlement is not effective.

\section{Precautionary Principle}

From the principle of subsidiarity in its application is contained precautionary principle. Precautionary in the
Indonesian English dictionary is meaningful, which relates to prevention or preventive measures. Thus prevention takes precedence and precedence from prosecution. Whereas if the action will be carried out gradually be done from the lightest action, medium and last action with heavy action. This precautionary principle can be found in Rio Declaration on Environment and Development (1992), which contains 21 principles to build a new and balanced global cooperation through inter-state cooperation.

The Rio Declaration has adopted several principles previously embodied in the Stockholm Declaration on the Human Environment which mandates sustainable development as a basis for global, regional and local action. This principle or principle implies that preventive or protection measures are better than remedial measures, and the lack of knowledge is not an excuse to prevent against actions potentially harmful to the environment.

This principle encourages to act quickly and appropriately (not delay) as a preventive measure in spite of scarcity and lack of evidence or availability of sufficient scientific data. The principle or principle 15 of the Rio Declaration is more aptly used in civil law, because of liability without proving an element of error. As for the criminal law, this precautionary principle implies that prevention takes precedence and precedence from prosecution. If the action is taken, then the implementation is done gradually, indirectly imposed the heaviest action, which is done gradually and tiered, from the lightest action, and if the violation is still done it will be subject to more severe sanctions. The precautionary principle requires that precautionary or supervisory measures from related institutions should be put forward (administrative law) rather than criminal law action. However, according to David Silalahi this principle is not clear position in Law No. 23 of 1997.

\section{Ultimum Remedium Principle}

The difficulties or barriers of the principle of subsidiarity to law enforcement practices in the Law on PLH have been revised in the Law on PPLH by changing the principle of subsidiarity to the ultimum remedium principle which is stated in the general explanation of Law Number 6 of PPLH as follows: "Environmental criminal law enforcement still pay attention to the principle of ultimum remedium which requires the application of criminal law enforcement as a last resort after the implementation of administrative law enforcement is considered unsuccessful.

The application of the ultimum remedium principle applies only to certain formal criminal acts, namely punishment for violations of waste water quality standards, emissions and disturbances ". Ultimum contains the last or last meaning, whereas the word remedium is found to be derived from the word remedy which contains the meaning of the medicine or repair. If ultimum remedium is linked to enforcement of environmental criminal law, it must be understood that administrative law is declared unsuccessful then criminal law is used as a last resort in improving the environment. Thus within the framework of criminal law operations associated with the principle of ultimum remedium is much more assertive than the operationalization of the principle of subsidiarity in the Law of Environmental Management. Only PPLH Law is very limiting with formal offense (related only to certain administrative law), whereas 
there are still many other formal offense but precisely criminal law utilized in primum remedium.

\section{The principle of subsosiality}

The meaning of the subsocialiteit principle is that a judge may not impose a penalty even if the defendant has been proven and found guilty, if the offense is too light or to see the circumstances at the time the act is committed or after the act has been committed. The principle of subsosiality is directly related to the principle of ultimum remedium. According to Syahrul Machmud in modern criminal law, the defendant is not always sentenced to imprisonment, since many other alternative penalties can be applied to the defendant, this has been contained in the Criminal Code (RUU KUHP). Nevertheless, in Indonesia has not yet been approved by modern criminal law, as evidenced by the new PPLH Law, always applying the imprisonment to the defendant, even to officials who do not perform their duties properly can also be sentenced to imprisonment. So that the entire penal institution is overpopulation (over capacity). Such circumstances are actually less favorable for the development of the criminal law itself.

\section{Principle In Dubio Pro Reo}

Since the Law on PPLH was enacted on 3 October 2009, there has been a change of law on environmental law. Whether replacing the principle of subsidiarity by the ultimum remedium principle it can affect the application of formal offenses to enforcement of environmental criminal law. How is the treatment of criminal law against the amendment of the law?Criminal sanctions in the Law PPLH more severe when compared with Law PLH, because the Law on PPLH known minimal sanctions and minimum penalties and penal sanctions are much heavier when compared with UUPLH.

Similarly, the treatment of formal offenses except on violations of waste water quality standards, emission standards, and quality standards of disturbance, all applied directly to criminal law or criminal law functioned primum remedium. Whereas in the Law of PLH on the formal offense of criminal law functioned in ultimum remedium. Thus if the violation of environmental law is carried out before UUPPLH is enacted, the violator is still subject to UUPLH because it is lighter, this is known as the principle of in dubio pro reo or subject to lucrative / lighten the defendant.

Proving a mistake is not easy because it must first be proven a causal relationship between the act of pollution and the loss of the patient. Especially for environmental issues, the obligation to prove or explain the causal relationship of the perpetrators of the polluters (poluter) to the victim, is difficult, especially in the field of environment to analyze a pollution requires explanation that is scientific, technical and special (transfrontier) so that if the scale is widespread and serious, then proving the causal relationship in the case of pollution is even more difficult. Therefore, the adoption of a regular system of responsibility does not reflect a sense of justice [15]. In the case of criminal acts of environmental damage caused by corporate activities in Article 88 UUPPLH has set explicitly about strict liability:

"Any person whose actions, activities and / or activities use B3, produce and / or manage B3 waste, and / or poses a serious threat to the environment responsible for the losses incurred without the need to prove the element of error".

In strict liability, a person is liable whenever losses arise. This benefits the victims as the victims are released from heavy burden to prove a causal relationship between their losses and the actions of the defendant. In addition, the "potential poluter" will be able to take better care of the level of care (level of care) as well as the level of activity (level of activity). These two things are the advantages of strict liability from the concept of error. According to L.B. Curson, the principle of strict liability is based on the following reasons [16]:

a. It is very essential to ensure compliance with certain important rules necessary for social welfare.

b. the proving of mens rea would be very difficult for violations related to social welfare

c. the high level of social hazard posed by the acts concerned.

Criminal charges are committed and criminal sanctions are imposed on those who give orders or who act as leaders without needing to remember whether the persons committed the crime on their own or together. Under this provision, it can be said that the so-called corporate crime is [17]:

1. Criminal acts committed by those acting for and on behalf of the corporation;

2. Criminal acts committed by the person who gave the order or the leader or the corporation itself; and

3. Criminal acts committed by a lowly employee who merely executes the orders of his superior, can not be prosecuted and are subject to criminal sanctions.

The existence of the provisions on corporate crime, then the entrepreneurs will be more careful in running the company. If the entrepreneur, for example, commits an environmental crime, then he and his company may be subject to criminal sanctions whose penalties are exacerbated by one-third.

Based on the theory of criminal law, there are two criteria to determine the corporation as the perpetrator of crime, namely the criteria of roling and the criteria of wire (iron wire). According to the criteria of roling, a corporation may be held criminally liable if a prohibited act is committed in the performance of a corporation's duties or to achieve the objectives of the corporation. Based on the theory of barbed wire criteria, corporations can be sentenced to criminal punishment if fulfilled with two conditions. First, corporations have de jure and de facto power to prevent or stop perpetrators from engaging in activities that are prohibited by law. Second, the corporation receives an act of acceptance as part of corporate policy[18].

\section{Criminal Sanctions of Environmental Protection Management Act}

The criminal provisions in the PPLH Law are divided into two formulas of offense, namely material offense and formal offense. The difference between material offense and formal offense is:

a. The material offense is a criminal offense whose formulation provides a criminal penalty against an 
action that results from an act (the causality between the act and the consequences of the deed).

b. Formal offense is a crime whose formulation provides a criminal penalty against a prohibited act, regardless of the consequences of the deed.

Material offenses are contained in article 98, section 99 which essentially regulates the legal management of individuals or legal entities that have committed an act or act which resulted in pollution or damage to the environment, and article 112 imposed on government officials authorized in the field of environmental monitoring .

As for the type of formal offense there are 16 (sixteen) articles in the PPLH Law. Articles 100 to 111, then Articles 113 to 115 . The formulation of his actions includes:

a. Article 100 contains formulation of formal offense on violation of waste water quality standard, emission quality standard, quality standard of disturbance.

b. Article 101 concerning the act of releasing and / or distributing genetically engineered products to environmental media that is contrary to laws or environmental permits.

c. Article 102 concerning the processing of B3 waste without permission.

d. Article 103 concerning generating B3 waste and not processing.

e. Article 104 refers to dumping waste and / or material to environmental media.

f. Article 105 concerning the incorporation of waste into the territory of the Unitary State of the Republic of Indonesia.

g. Article 106 concerning the incorporation of B3 waste into the territory of the Unitary State of the Republic of Indonesia.

h. Article 107 concerning the incorporation of B3 waste into the territory of the Unitary State of the Republic of Indonesia.

i. Article 108 on burning land.

j. Article 109 is about business activities without any environmental permit.

k. Article 110 concerning the preparation of Environmental Impact Assessment (AMDAL) without the certificate of competence in the preparation of AMDAL.

1. Article 111 concerning the officials who give environmental permit without AMDAL or UKL-UPL.

m. Article 111 paragraph (2) concerning the officials who give the business license without the environmental permit.

n. Article 113 of the UUPPLH concerning providing false information, destroying information, or providing untrue information required in relation to the supervision and enforcement of laws relating to the protection and management of the environment.

o. Article 114 on the party responsible for business activities that do not implement the government coercion.

p. Article 115 concerning acts intentionally preventing, obstructing or foiling the execution of the duties of environmental supervisors and / or civil servant investigators.

In case of non-compliance by business actors to perform reclamation and post-mining obligations as agreed before the

IUP is issued, it refers to potential damages to the environment:

1. Damage to the soil that also causes damage to the biological elements in the ecosystem.

2. Water pollution caused by the formation of Mining Acid Water

The availability of nutrients is the most important factor for plant growth. Acidic soils contain heavy metals such as Iron, Copper, Zinc, all of which are micro nutrients. Due to the advantages of micro nutrients can cause poisoning in plants, it is characterized by rotting roots of plants so that plants wither and eventually will die.

Then the applicable legal basis is regarding exceeding the standard criteria of environmental damage Article 98 paragraph (1) jo article 1 number 15 which states:

"Any person who deliberately commits an act which results in exceeding the ambient air quality standard, water quality standard, seawater quality standard or environmental damage criteria shall be punished with imprisonment of a minimum of 3 (three) years and a maximum of 10 (ten) years and a fine of at least Rp3,000,000,000.00 (three billion rupiah) and a maximum of Rp10,000,000,000.00 (ten billion rupiah). "

This article is a material offense which means that there has been pollution and / or environmental damage without seeing the causality between the actions and the results of the deed, which resulted in the community having been restless because of the nature of the damaged or polluted environment, and of course the acts of the perpetrator is relatively heavy.

Reclamation and post-mining should be implemented as soon as possible after the end of business activities, making the appropriate legal instrument is a legal instrument that followed the violation, so that the criminal act of environmental pollution can be enforced well and not repeatedly done, environmental crime law is the nearest road that can be done to fix it and negate the potential for similar occurrences.

\section{REFERENCES}

[4] Haryono and W. Suwarty, Hukum Lingkungan. Jakarta: Universitas Islam Jakarta, 2007.

[5] Irwan and Z. Djamal, Prinsip-Prinsip Ekologi. Jakarta: Sinar Grafika, 2007.

[6] R. H. Prawiro, Ekologi-Lingkungan Pencemaran. Semarang: Satya Wacana, 1979.

[7] Z. D. Irawan, Prinsip-Prinsip Ekologi. Jakarta: Sinar Grafika, 2007.

[8] Harsono, No Title. 2010.

[9] D. Dwidjoseputro, Ekologi Manusia Dengan Lingkungannya. Jakarta: Penerbit Erlangga, 1990.

[10] M. Soedomo, Pencemaran Udara. Bandung: Penerbit ITB, 2001.

[11] P. J. Subagyo, Hukum Lingkungan. Jakarta: Rineka Cipta, 1999.

[12] R. Sutanto, Dasar-Dasar Ilmu Tanah. Yogyakarta: Penerbit Kanisius, 2005. 
[13] A. Hamzah, Penegakan Hukum Lingkungan. Jakarta: Sinar Grafika, 2005.

[14] J. Tjahyan, “Tinjauan Yuridis Asas Subsidiaritas Yang Diubah Menjadi Asas Ultimum Remedium Dalam Penegakan Hukum Pidana Lingkungan," J. Karya Pendidik., vol. I, no. 2, p. 29, 2014.

[15] N. H. T. Siahaan, Hukum Lingkungan dan Ekologi
Pembangunan. Jakarta: Erlangga, 2004.

[16] S. Sunarso, Hukum Pidana Lingkungan Hidup. Jakarta: PT. RINEKA CIPTA, 2005.

[17] H. Rhiti, Penyelesaian Sengketa Lingkungan Hidup. Yogyakarta: Universitas Atmajaya Yogyakarta, 2006.

[18] S. Husin, Penegakan Hukum Lingkungan Indonesia. Jakarta: Sinar Grafika, 2009. 